\title{
SALA DE AULA, SALA DE ESTAR DA CANÇÃO POPULAR BRASILEIRA $^{1}$
}

Na ponta da língua beijos, canções e figuras de gramática dão ritmo às aulas de Português

\author{
AULA DE PORTUGUÊS ${ }^{2}$ \\ A linguagem \\ na ponta da língua, \\ tão fácil de falar \\ e de entender. \\ A linguagem \\ na superfície estrelada de letras, \\ sabe lá o que ela quer dizer? \\ Professor Carlos Góis, ele é quem sabe, \\ e vai desmatando \\ o amazonas de minha ignorância.
}

Figuras de gramática, esquipáticas,

atropelam-me, aturdem-me, seqüiestram-me.

Já esqueci a língua em que comia, em que pedia para ir lá fora, em que levava e dava pontapé, a língua, breve língua entrecortada do namoro com a prima.

O português são dois; o outro, mistério.

\section{O AUTOR}

Ivanhoé Robson Marques Bonatelli

Professor de Língua Portuguesa no primeiro e segundo graus, em São Paulo.
O poema acima transcrito pertence à parte denominada Primeiro Colégio, em BOITEMPO, livro que condensa um dos temas drummondianos mais cristalinos: a mineiração da memória, a escavação líri- 
ca, lúcida, dolorosa "de cacos, de buracos/de hiatos e de vácuos/ de elipses, psius..." que compõem, em mosaica desarmonia, nossa vida passada. No poema, ao revisitar o menino Carlos e suas impressões acerca das aulas de Português, Drummond expõe com vigor um dos pontos de inflexão mais ásperos para todo professor: como promover a intersecção dialética entre a sua linha pedagógica (às vezes preso à grade curricular, à normatividade da língua etc) e a linha de vida do aluno, com suas curvas únicas, seu vocabulário que se vivifica toda manhã com o bombardeio de gírias ou expressões fotográficas do momento, seu modo de se vestir e de pensar, apêndice do que jorra nas pistas de dança, de skate, de patins in-line, do fundo-falso de TV's e MTV's, das mil tribos sonoras, que vão da dance music ao pagode, do funk ao brega, do samba de morro à música clássica.

Em linhas gerais, puxando o peixe para o mar da língua portuguesa e literatura, o nó a desatar é o seguinte: existe um conteúdo mínimo a ser seguido pelo professor, existe o aluno com sua bagagem e seu atlas de referências individuais, e o mútuo desconforto de ambas as partes. Muitas vezes, o que se passa em sala de aula é um diálogo fictício - o discurso do professor, via voz ou giz, chega ao aluno e, de forma compulsiva, entra por um ouvido e sai intacto pelo outro, reverbera nas paredes e perde-se para sempre, quando uma campainha anuncia o fim da aula ou o começo de algo bem melhor: a hora do recreio.

De forma lapidar, Drummond nos diz que:

\section{HÁ TANTOS DIÁLOGOS ${ }^{3}$}

Diálogo com o ser amado

o semelhante

o diferente

$o$ indiferente

$[\ldots]$

Por que não haveria o diálogo (vivo, sagaz, fértil) entre professor/aluno, a conversação em que, com certeza férrea, a troca de saberes e quereres comuns não seria um jogo de aparências, um simulacro do que se chama aprendizagem?

Pensando na aula de Português do poema de Drummond, talvez não fosse fantasiar demais esperar que um dia, na ponta da língua, beijos e figuras de gramática convivam em paz ou em estado de beligerância, ou melhor, que a gramática busque no beijo do aluno um elo comum entre eles e vice-versa, e que essa troca de afagos ou insultos estabeleça um canal de

3. ANDRADE, Carlos Drummond de. Discurso de primavera. In: Poesia e Prosa. 6 ed. Rio de Janeiro: Nova Aguilar, 1988. p. 850. 
comunicação mais transparente, em que experiências pessoais possam trafegar de lá para cá, par a par, fugindo do velho script professor-lousa-alunos-matéria do dia-lição de casa.

\section{NAS CANÇÕES PREFERIDAS, AS FIGURAS DA GRAMÁTICA}

Pensando em minhas aulas de literatura, um meio que se mostrou eficaz para diminuir a distância entre o discurso do professor e a recepção do aluno, foi o uso intenso da canção popular brasileira, o que serviu para despir a disciplina da pecha de lugar de idéias e figuras mumificadas e mostrar que nas letras de Caetano Veloso, Chico Buarque, Cartola e Gilberto Gil - só para citar quatro compositores de primeira linha - imagens e recursos expressivos que pertencem à tradição literária se fazem presentes, configurando um movimento típico em literatura: um texto não vem do nada absoluto, mas se insere em uma tradição cultural.

O trabalho de ouvir e perceber com mais apuro a luminosidade que se oculta em certas canções populares trabalhadas em classe faz parte de uma prerrogativa minha, como professor: a de demonstrar que a literatura é um organismo vivo, não um museu de palavras que trata de um mundo perdido no tempo.

Tempo, eis a palavra. Ao constatar, por exemplo, que certas canções de Chico Buarque, entre as quais, Sem Fantasia e Tatuagem, assemelham-se às cantigas de amigo medievais, o aluno percebe com clareza que em literatura o tempo pretérito não se esgota em si mesmo, mas contamina com seu poder de ressurreição o tempo presente: eis, em Tom, Caetano e Cia. Ltda. os velhos temas com o figurino novo de piano, guitarra, teclado, violão de aço, flauta ou na melodia rústica do trio conga, pandeiro e marimba.

A par dessas considerações, desenvolvi com os alunos do primeiro colegial, no segundo bimestre de 95, um trabalho que, em síntese, consistia nos seguintes passos: a partir de conceitos literários estudados nos primeiros meses do ano (tema, motivo recorrente, metalinguagem, por exemplo), cada grupo gravaria em fita cassete uma seleção de oito canções, cuja escolha obedeceria a critérios previamente estabelecidos. Dois critérios eram leoninos. O primeiro era que, xenofobismos à parte, as canções deveriam apresentar letra em português; o segundo tratava-se de um adendo democrático: na escolha do repertório, o gosto pessoal do professor não valeria como critério de avaliação do trabalho: sendo pagode, rock mais ameno ou mais pesado, samba, charm, funk, forró, música dita sertaneja e tudo mais, o que estava em jogo era a relação íntima en- 
tre canção e o que se pedia dela. $\mathrm{O}$ aluno, livre para mapear a fita cassete com seu repertório musical, ficasse tranqüilo: o professor estava preparado para ouvir de Xitãozinho e Chororó a Gabriel, o Pensador.

\section{CAÇA Às CANÇÕES}

A escolha do repertório seguia o seguinte roteiro:

\section{Canção um}

recurso expressivo: a função metalingüística da linguagem.

\section{Canção dois}

tema: a solidão.

\section{Canção três}

tema: o ciúme.

\section{Canção quatro}

motivo recorrente: a noite.

\section{Canção cinco}

motivo recorrente: a Lua.

\section{Canção seis}

tema: algum problema social - a pobreza, a vida nas camadas mais pobres da população, a seca, os meninos de rua etc.

\section{Canção sete}

tema: a sensualidade, o erotismo.

\section{Canção oito}

Assunto: a cidade de São Paulo.

Além da fita cassete contendo as canções selecionadas, houve um trabalho de transcrição e comentário das respectivas letras. Por exemplo, se a Canção um fosse Rebento, de Gilberto Gil, o aluno esclareceria como a metalinguagem está presente no texto.

\section{CADA CABEÇA, UMA SENTENÇA MUSICAL}

Abaixo, reproduzo o tecido de dúvidas, apreensões e descobertas que se alinhavaram durante os quase dois meses de realização da pesquisa e produção da fita cassete:

Busco o estilo exato

A tática eficaz

do rock ao jazz

do lied ao samba

ao brega

(Errática, de Caetano Veloso) 
O fragmento de Errática, de Caetano Veloso, expõe o primeiro entrave com que os alunos se depararam no início das pesquisas: a diversidade de "gostos pessoais", óbvio ululante, levaria o repertório a ser uma espécie de colcha de retalhos musicais, pois, afinal, no interior de um grupo, o menino A era um apreciador fanático do pagode de grupos como Os Morenos, Só pra Contrariar; o B, um fã incondicional do reggae da banda Cidade Negra; a menina $C$, pensando que o ano de 68 ainda não terminou, não abria mão da psicodelia dos Mutantes; por fim, o menino D, com cadeira cativa nos shows estrondosos (em todos os sentidos) do rock-forró dos Raimundos, achava imprescindível um som "mais pesado".

Expliquei à classe, antes que o radicalismo étnico-musical implodisse os grupos, que a riqueza das fitas, em parte, estaria na diversidade de estilos que as recheassem. A convivência, dentro das mesmas fronteiras, da voz épica de uma Dalva de Oliveira com o canto-falado do rap tupiniquim de Gabriel, o Pensador, apontava para as múltiplas faces de nosso arco-íris cultural, capaz de abrigar tantas variações melódico-poéticas de um mesmo tema. Que haja Gil, Roberto Carlos, Zezé di Camargo \& Luciano, Gal, Bethânia, Titãs, Mamonas Assassinas, Pato Fu e Chico Buarque e, por fim, paratodos, que haja o poder de escolha. Cada cabeça, uma sentença musical.

\section{O TEMPO CANTA}

Ao ouvir atentamente as fitas cassetes, um dado objetivo evidenciase: em sua maioria, as seleções demonstram que certos movimentos e figuras do cancioneiro popular hoje aparecem como modelos sacralizados de bom gosto estético-musical. Caetano Veloso (o anjo transgressor do Tropicalismo) e Chico Buarque (com suas diversas faces: a da crítica social ou a mais intimista) são referências básicas para os alunos. Deles, pululam nos trabalhos verdadeiros clássicos: de Veloso, Outras palavras, $\mathbf{O}$ ciúme, Lua de São Jorge, Sampa. De Buarque, Palavra, Brejo da cruz, Tatuagem, Meu Guri, Pedro pedreiro. Gilberto Gil completa o trio de "os mais mais" com Metáfora, Drão, Parabolicamará, Domingo no parque. Fora os cantores/compositores, as vozes primorosas de Gal Costa, Maria Bethânia e João Gilberto são freqüentes nos repertórios.

Às claras, os alunos não negaram que o culto às chamadas estrelas da música brasileira vem por assimilação das discotecas de pais e mães, em geral profissionais liberais bem sucedidos ou professores universitários. "Meu pai é fã da bossa nova" ou "minha mãe não perdia um festival na TV Record", eram frases comuns entre os alunos.

Pode-se afirmar que os meninos são filhos de dois tempos musicais distintos: o da tradição, que inclui, além dos nomes citados acima, Raul Seixas, Mílton Nascimento, Rita Lee e outros, e o atual, representado por Marisa Monte, Itamar Assumpção e a banda Isca de Polícia, Suzana Salles, 
Carlinhos Brown, o pagode romântico de Os Morenos ou do Raça Negra, o som "sertanejo" de Zezé di Camargo \& Luciano, o axé music de Netinho e Banda Mel etc. Certo aluno, ao comentar comigo o trabalho de seu grupo, disse, enfático, que Ronda, de Paulo Vanzolini, na antológica voz de Marisa Gata Mansa(!) e a pérola Puteiro em João Pessoa, de os Raimundos, foram suas escolhas pessoais. Estamos diante de um menino que incorpora simultaneamente ao rol de suas preferências duas músicas opostas em todos os sentidos. À carga trágica da letra de Vanzolini, com sua história de amores e cenários baratos em que permeiam bilhar, jogo de dados e cenas de sangue na avenida São João, junta-se a quintessência do mau gosto e deboche explícito de os Raimundos.

Uma análise sumária parece revelar que o sentido da tradição, por exemplo, que permite traçar uma linha que sai de Mário Reis, passa por João Gilberto e desemboca em Caetano Veloso, ou que vem de Noel Rosa até bater à porta de um Chico Buarque, perdeu-se entre os adolescentes. Perdeu-se talvez seja uma afirmativa categórica demais a um questionamento que pede, com certeza, uma análise mais elaborada, mas que está fora dos parâmetros deste artigo. Saber, contudo, que, bem ou mal, os alunos estão vinculados a um pretérito musical que reverbera neles como matéria ainda candente, é uma constatação excepcional para mim.

Além da pura apreensão de certos recursos literários, o trabalho dá mostras de que a memória afetiva de certa época (anos 60, Tropicalismo, Jovem Guarda, Festivais da Record etc.), em constante luta corporal com o chamado novo, vive em adolescentes de 15 anos.

Nas férias de julho de 95, ao ouvir à exaustão mais uma vez todas as seleções, lembrei-me de Chico Buarque em Tempo e Artista, canção do álbum Paratodos (RCA, 1993), em que ele discute poeticamente que o "tempo canta" e eterniza a voz do artista, este tecelão de palavras e melodias que buscam sempre o infinito. Das caixas acústicas às vezes irrompia o som estridente de um rap, ou a voz em plumas de Elizeth Cardoso. Porém, antes de tudo e misturado aos acordes, vinha o rosto de cada menino ou menina do primeiro colegial e a certeza férrea de que ali, impressas na pele tênue da fita de dióxido de cromo, um pouco do tempo deles cantava, um pouco do tempo deles eternizava-se em mim. Caetano Veloso disse: "como é bom poder tocar um instrumento". Mas como é bom cantar, também. 
Resumo: Professor de Português ensina literatura e gramática através das músicas populares preferidas dos alunos, num processo de integração com a História.

Palavras-chave: música popular, Português, aluno, professor, sala de aula
Abstract: A Portuguese educator teaches literature and grammar using students' favorite songs, in a process of integration with History.

Key-words: popular music, Portuguese, student, professor, classroom 